\title{
Streptomyces scabiei subsp. xuchangensis, A NOVEL STREPTOMYCETE ISOLATE FOR STAUROSPORINE PRODUCTION AND A WHEAT TAKE-ALL CONTROL AGENT
}

\author{
CAIYI WEN ${ }^{1 *}$, DONGGUANG ZHENG1, SHUNSHAN SHEN1, JIANGUANG CHEN1, WEICHENG LIU2 AND TING LIU2 \\ ${ }^{1}$ College of Plant Protection, Henan Agricultural University, Zhengzhou, Henan 450002, China. \\ 2Institute of Plant and Environmental Protection, Beijing Academy of Agriculture and Forestry Sciences, Beijing 100097, China. \\ *Corresponding Author: Email- cywen080@hotmail.com
}

Received: 28 March, 2012; Accepted: August 09, 2012

\begin{abstract}
The streptomycete strain SCY114 was isolated from a soil sample of Xuchang in Henan province, China. It possessed smooth grey spores borne in rectiflexible and spiral chains and was capable of using all of the International Streptomyces Project sugars. The melting temperature and $\mathrm{G}+\mathrm{C}$ content were $81.8^{\circ} \mathrm{C}$ and $61.6 \mathrm{~mol} \%$, respectively. The level of $16 \mathrm{~S}$ rRNA gene sequence similarity between strain SCY114 and S. scabies ATCC49173 was $99.8 \%$. However, the values of DNA-DNA relatedness between strain SCY114 and S. scabies ATCC49173 was $65.2 \%$, and the strain SCY114 did not exhibit pathogenicity towards potato plants. Based on the phenotypic and genotypic evidence, strain SCY114 was identified as a subspecies of the Streptomyces scabiei, for which the name Streptomyces scabiei subsp. xuchangensis is proposed. Strain SCY114 strongly inhibited the in vitro mycelial growth of Gaeumannomyces graminis var. tritici as well as various other plant pathogenic fungi. The filtered culture broth of strain SCY114 was substantially more effective at controlling wheat take-all compared to the silthiofam, and the disease was reduced by $78.2 \%$. An antifungal antibiotic was isolated from the fermentation broth of strain SCY114 using a series of chromatographic procedures. The molecular formula of the antibiotic was determined to be $\mathrm{C}_{28} \mathrm{H}_{26} \mathrm{~N}_{4} \mathrm{O}_{3}$, and on the basis of the NMR data, the antibiotic was confirmed to be staurosporine.
\end{abstract}

Keywords- Streptomyces scabiei, Staurosporine, Antifungal activity, Wheat take-all.

Citation: Caiyi Wen, et al. (2012) Streptomyces scabiei subsp. xuchangensis, a Novel Streptomycete Isolate for Staurosporine Production and a Wheat Take-All Control Agent. International Journal of Microbiology Research, ISSN: 0975-5276 \& E-ISSN: 0975-9174, Volume 4, Issue 7, pp.-282-289.

Copyright: Copyright@2012 Caiyi Wen, et al. This is an open-access article distributed under the terms of the Creative Commons Attribution License, which permits unrestricted use, distribution and reproduction in any medium, provided the original author and source are credited.

\section{Introduction}

Streptomyces is the largest antibiotic-producing genus of Actinobacteria, producing antibacterial, antifungal and anti-parasitic drugs, and also a wide range of other bioactive compounds [50]. The search for new antimicrobials, especially those produced by Streptomyces species, has not been limited to medical uses but also extends to crop protection [16]. The use of Streptomyces as a potential biological control agent has been proposed because these microorganisms produce a wide diversity of useful bioactive metabolites. So far, many fungicide products based on antibiotic metabolites or live mycelia and spores of Streptomyces are being commercially used in pest control [49]. For example, streptomycin and oxytetracycline were used in the United States for crop disease management [27]. Streptomyces sp. strain 5406 has been used in China for the past 35 years to protect cotton crops against soilborne pathogens [47]. Blasticidin-S, kasugamycin and polyoxin were used in the control of rice blast and many other leaf, stem, and fruit spots in Japan [1].

Roughly 550 species of Streptomyces are recognized at present, but new ones are still being discovered (http://en.wikipedia.org/wiki/
Streptomyces). Among them, only a small number of Streptomyces species are known as plant pathogen. S. scabiei is well known as one of three species of Streptomyces that can cause common scab of potato [25]. Most research on S. scabiei has focused on the taxonomy and pathogenicity to this host plant for many years. More recently, researchers have been studying the biological control potential and the antibiotic production capacity of $S$. scabiei. It was reported that $S$. scabiei and its toxin thaxtomin A could induce plant defense mechanisms such as ion flux [44], programmed cell death in an Arabidopsis cell suspension [4,7] and scopoletin biosynthesis in Tobacco and Arabidopsis thaliana [23]. Yoo et al. reported that S. scabiei subsp. chosunensis M1037 could produce nonadecanoic acid, which exhibited cytotoxic activities in various human cancer cell lines [54,55]. The Streptomyces scabiei PK-A41, isolated from a soil sample of Ko-yang in Korea, was viewed as a causal agent of common scab disease, however, the strain inhibited antifungal and anti-oomycete activity against various plant pathogenic fungi by producing antifungal compounds [12]. In this study, the actinomycete strain SCY114 was identified as a subspecies of the Streptomyces scabiei, which differed from other Streptomyces scabiei strains in that it showed no pathogenicity towards potato plants, 
and instead produced an antigungal compound identified as staurosporine. The present paper describes the identification and antifungal activity of strain SCY114, as well as the purification procedure and the chemical structure of the antifungal component.

\section{Materials and Methods}

\section{Isolation of Strain SCY114}

The soil samples were collected from Xuchang in Henan province, China, in 2010. The soil was sampled up to a depth of $10 \mathrm{~cm}$ after removing approximately $3 \mathrm{~cm}$ of the soil surface. The samples were placed in polyethylene bags, closed tightly and stored at $4{ }^{\circ} \mathrm{C}$. The following screening procedure was adopted for the isolation of Streptomyces [18]: Pure isolates were obtained from selected colonies for repeated sub-culturing. After antimicrobial activity screening, the isolated Streptomyces strains were maintained on Gause's No. 1 synthetic medium (G-1) at $4^{\circ} \mathrm{C}$ for further study. Total 128 of streptomyces isolates were obstained from soli samples. Among them, one streptomyces isolate, strain SCY114, was screened by dual culture method using Gaeumannomyces graminis var. tritici as target plant pathogen.

\section{Taxonomy of Strain SCY114}

The micromorphology of strain SCY114 cultured on a G-1 plate at $37^{\circ} \mathrm{C}$ for $7 \mathrm{~d}$ was examined using a scanning electron microscope (S-3400N-П, HITACHI, Japan) and the spores were observed. The cultural characteristics of strain SCY114 and reference strain S. scabies ATCC49173 (provided by the China General Microbiological Culture Collection Center, CGMCC) were determined according to Waksman [48], Lechevalier and Lechevalier [22], and Bergey's Manual of Systematic Bacteriology [52]. Various International Streptomyces Project (ISP) media were used for the analyses of the cultural characteristics [38]. The whole-cell hydrolysate was analyzed according to Becker et al. [2]. The fatty acids were extracted, methylated and analyzed using GC according to the standard Sherlock MIDI (Microbial Identification) system, and the analysis of the cellular fatty acid pattern used exponential phase cultures [19]. The $G+C$ content of the test strain DNA was measured using the thermal denaturation method [26] with Escherichia coli AS 1.365 as a control. DNA-DNA hybridization between strain SCY114 and S. scabies ATCC49173 was performed as described by He et al. [13].

The genomic DNA extraction of strain SCY114 was performed as described by Bramwell et al. [3]. The $16 \mathrm{~S}$ rDNA gene was amplified with the primers forward (5-AGAGTTTGATCCTGGCTCAG-3) and reverse (5-AAGGAGGTGATCCAGCCGCA-3) [5]. The 16S 23S rRNA intergenic spacer region (ISR) sequence was amplified with the primers forward (5-GAAGTCGTAACAAGG-3) and reverse (5CAAGGCATCCACCGT-3) [15]. The amplified PCR products were purified from a $1.5 \%$ agarose gel using the TaKaRa Agarose Gel DNA Purification Kit Ver. 2.0 and were ligated into the pMD $^{\circledR}$ 18-T vector (TaKaRa Biotechnology (Dalian) Co., Ltd.) according to the manufacturer's instructions. The plasmids containing the PCR products were isolated using the TaKaRa DNA Fragment Purification Kit Ver. 2.0 (TaKaRa Biotechnology (Dalian) Co., Ltd.). The cloned inserts (16S rDNA and 16S 23S rRNA ISR) were sequenced by TaKaRa Biotechnology (Dalian) Co., Ltd. The phylogenetic position of strain SCY114 was assessed using the BLAST program from NCBI GenBank. The nucleotide substitution rates were calculated and the phylogenetic trees were constructed with the neighbor-joining method $[8,17,37]$ using the MEGA software version 4.0 [43].

\section{Pathogenicity Assay}

The pathogenicity assay of strain SCY114 was conducted according to the modified method described by Loria et al. [24]. Briefly, immature potato tubers (cv. Youjin, provided by the Potato Research Institute of Benxi, China) were sterilized in $0.05 \% \mathrm{NaOCl}+$ $0.1 \% \mathrm{CaCO}_{3}$ for 3 min and rinsed twice with sterile $\mathrm{H}_{2} \mathrm{O}$. The tubers were punctured with a sterile cork borer $(0.6 \mathrm{~cm}$ in diameter) and inoculated with the spore suspensions $\left(10^{8} \mathrm{spores} / \mathrm{ml}\right)$ of the test strains. The strains S. scabies ATCC49173 was inoculated as controls. The inoculated tubers were incubated in a moist dew chamber at $26{ }^{\circ} \mathrm{C}$ for $5 \mathrm{~d}$ in the dark. The tubers exhibited necrosis and collapse symptoms surrounding the pit. Three tuber replicates were used per treatment.

\section{In Vitro Antifungal Activity Assay}

A total of 16 plant pathogenic fungi were collected from the Laboratory of Plant Disease Management of the Plant Protection College, Henan Agricultural University, China. These strains included Alternaria alternata, Bipolaris maydis, Botrytis cinerea, Colletotrichum orbiculare, Curvularia lunata, Exserohilum turcicum, Fusarium oxysporum, Gaeumannomyces graminis var. tritici, Glomerella cingulata, Macrophomina phaseoli, Phytophthora capsici, Pyricularia oryzae, Pythium graminicola, Rhizoctonia cerealis, Sclerotinia fuckeliana and Ustilaginoidea virens. A dual culture assay was performed to assess the potential biocontrol activities of strain SCY114 against the target fungi listed above in 9-cm Petri dishes. In the dual culture assay, two 2-mm mycelial disks of strain SCY114 from a 5-d-old culture grown on a Gause's synthetic agar plate were inoculated onto potato dextrose agar (PDA) plates at a distance of $60 \mathrm{~mm}$. The paired cultures were incubated at $26 \pm 2^{\circ} \mathrm{C}$. After $3 \mathrm{~d}$, a $5-\mathrm{mm}$ mycelial plug from an actively growing fungal culture was placed between the two SCY114 disks (at the center of the plate). The cultures were then sealed and incubated at $26 \pm 2{ }^{\circ} \mathrm{C}$. The mycelial growth on the plates was measured daily over $7 \mathrm{~d}$ for the formation of an inhibition belt. There were 3 replicates for each plant pathogenic fungi, and the experiment was repeated twice. The inhibition belt is defined as the distance from the edge of the colony of strain SCY114 to that of the proximal target fungus (Fig. 1).

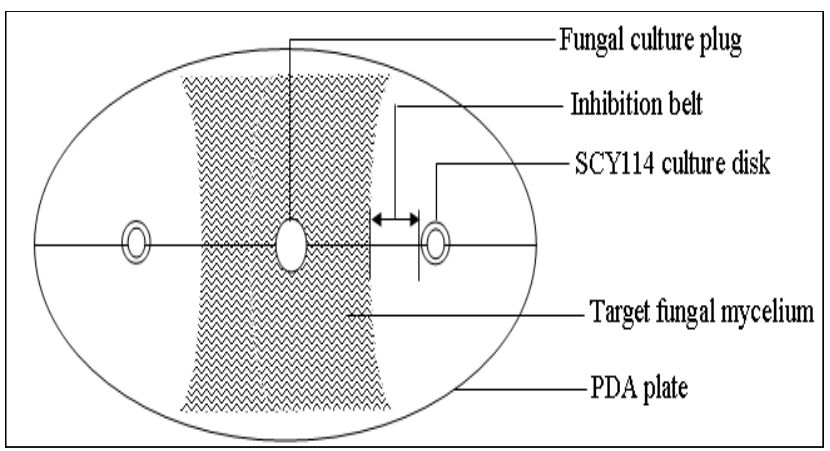

Fig. 1- A schematic diagram showing the method of dual culture assay for testing the antifungal activity of strain SCY114 against various plant pathogenic fungi 
The activity assay of ethyl acetate extract from the culture filtrate of strain SCY114 (culture medium including soluble starch 2\%, soybean cake powder $4 \%, \mathrm{MgSO}_{4} \quad 0.075 \%, \mathrm{~K}_{2} \mathrm{HPO}_{4} \quad 0.1 \%$ 、 $\mathrm{FeSO}_{4} \cdot 7 \mathrm{H}_{2} \mathrm{O} 0.001 \%$. incubated on a rotary shaker at $28{ }^{\circ} \mathrm{C}$ for 7 d) was performed as described above the method of dual culture assay. Instead of mycelial disks of strain SCY114, 100 $\mu$ l of crude extract was loaded on the plate by stainless steel columns and the inhibition zone would appear around the columns containing active substance.

\section{The Greenhouse Assays for Biocontrol Activity Against Wheat Take-All}

Greenhouse pot experiments were conducted under standard greenhouse conditions at $26^{\circ} \mathrm{C} \sim 28^{\circ} \mathrm{C}$. Treated and control wheat seeds were planted in the greenhouse in polypropylene pots (10 $\mathrm{cm}$ high, $12 \mathrm{~cm}$ in diameter). Each pot was filled with $400 \mathrm{~g}$ of sieved sandy loam soil (sand: loam mixture, $1: 1(\mathrm{~g} / \mathrm{g})$ ) that had been artificially inoculated with $3.5 \mathrm{~g}$ of Ggt-infected oat kernels. A total of 15 surface-sterilized winter wheat seeds (cv. Zhengmai93) were sown, and the seeds were covered with a 2-cm layer of soil. Immediately after sowing, the soil surface of each pot was drenched with the culture filtrate $\left(30 \mathrm{ml} \mathrm{pot}^{-1}\right)$ of strain SCY114. The pots were randomly distributed in the greenhouse, and their positions were changed weekly to avoid any positional effects on the experiment. Three controls were included: (a) a control inoculated with Ggt and untreated wheat seeds; (b) a control inoculated with Ggt and wheat seeds treated with a $12.5 \%$ silthiofam suspension; and (c) a control inoculated with Ggt and soil drenched with cultural suspensions of SCY311. Each treatment was performed in triplicate. The pots were watered once a week. After 6 weeks, the roots of the wheat plants were washed and evaluated for the incidence and severity of take-all. Each plant was assigned to one of five disease severity classes corresponding to the percentage of the root area exhibiting black vascular take-all lesions: Class $0=$ $0 \%$, Class $1=1 \%-10 \%$, Class $2=11 \%-30 \%$, Class $3=31 \%-$ $60 \%$ and Class $4=61 \%-100 \%$. The disease index (DI) was calculated using the formula described by Huang et al. [14]:

$$
\mathrm{DI}=\sum_{\mathrm{i}=0}^{4}\left(\mathrm{n}_{\mathrm{i}} \times \mathrm{i}\right) \times \sum_{\mathrm{i}=0}^{4}\left(\mathrm{n}_{\mathrm{i}}\right)^{-1}
$$

where $i$ is the severity class and $n_{i}$ is the number of plants assigned to the class $\mathrm{i}$. The calculated disease index values range from 0 (no disease) to 100 (the highest disease level). The disease reduction (DR) value was calculated using the following formula:

$$
\mathrm{DR}(\%)=100 \times\left(\mathrm{DI} \mathrm{l}_{\mathrm{ck}}-\mathrm{D} \mathrm{l}_{\mathrm{tr}}\right) / \mathrm{D} \mathrm{I}_{\mathrm{ck}}
$$

\section{Statistical Analysis}

The statistical analyses were performed with the general linear mode procedure using the Statistical Analysis System (SAS) software (SAS Institute, Cary, NC). The treatment means were considered statistically separate using the Fisher's protected least significant difference test with $\mathrm{P} \leq 0.05$.

\section{Isolation and Purification of the Antifungal Component}

The culture filtrate of strain SCY114 was precipitated with absolute ethyl alcohol. The filtered fluid was extracted three times with ethyl acetate at room temperature. After evaporation of the solvent under reduced pressure, the residue was suspended in methanol. The extraction was purified using silica gel column chromatography. The sample was eluted with a stepwise gradient of chloroform and methanol (0:100, 20:80, 40:60, 60:40, 80:20, and 100:0, $\mathrm{v} / \mathrm{v})$. Each $5-\mathrm{ml}$ fraction was collected and examined for antifungal activity. The active fractions were pooled and concentrated using a rotary evaporator, dissolved in chloroform-methanol $(1: 1, v / v)$, and purified via preparative thin-layer chromatography (TLC) on a 10 $\mathrm{cm} \times 20 \mathrm{~cm}, 0.2-\mathrm{mm}$-thick silica gel GF pre-coated plate (GF254, Qingdao Haisheng Co., Ltd., China). The TLC plates were developed with chloroform-methanol $(9: 1, \mathrm{v} / \mathrm{v})$ and visualized under UV light at $254 \mathrm{~nm}$. The active band was scraped off, extracted with methanol, and filtered through Xinhua paper No. 1. The concentrated methanolic extract was further purified using recycling preparative high-performance liquid chromatography (LC-9101, Japan Analytical Industry Co., Ltd.) with absolute methanol as the mobile phase at a flow rate of $3 \mathrm{ml} / \mathrm{min}$. Elution was monitored at $291 \mathrm{~nm}$ by a Lambda 35 UV/VIS detector (Perkin/EImer Co.). Finally, the pure compound was obtained as a pale yellow powder at a retention time of $24.833 \mathrm{~min}$ at $291 \mathrm{~nm}$. The antifungal activities of all fractions were assayed against strains of $\mathrm{G}$. graminis var. tritici using a paper disk assay method.

\section{Structure Elucidation of the Antifungal Compound}

The UV spectrum was measured on a Beckman DU 650 spectrometer. 1D- and 2D-NMR spectra were recorded on a Bruker AV-500 $\mathrm{MHz}$ NMR (500 MHz for ${ }^{1} \mathrm{H}$ and $125 \mathrm{MHz}$ for ${ }^{13} \mathrm{C}$ ) spectrometer with TMS as an internal standard. ESI-MS spectra were obtained using a JEOL JMS-700 MS mass spectrometer (JEOL, Tokyo, Japan).

\section{Results \\ Taxonomy of Strain SCY114}

Morphological observation of strain SCY114. Strain SCY114 formed aerial mycelia on various ISP and Gause's synthetic agar media. The spore chains were rectiflexible and spiral. The spores were oval or rod-shaped, and spores did not exhibit any obvious surface decoration.

The cultural characteristics of strain SCY114. The cultural characteristics of strain SCY114 are presented in Table 1.

Table 1- Cultural characteristics of the strain SCY114

\begin{tabular}{|lllll|} 
Media & Growth & Aerial mycelium & Substrate mycelium & Soluble pigment \\
aISP-1 & Good & Gray & Light brown & Light Brown \\
ISP-2 & Good & Gray & Dark brown & Dark brown \\
ISP-3 & Good & Gray & Light brown & b- \\
ISP-4 & Poor & White to gray & Colorless & - \\
ISP-5 & Moderate & Gray & Light brown & - \\
ISP-6 & Moderate & Gray & Dark brown & Melanin \\
ISP-7 & Good & White to gray & Dark brown & Melanin \\
\hline
\end{tabular}

a International Streptomyces Project media; ${ }^{b}$ No production

This strain exhibited robust growth on ISP-1, ISP-2, ISP-3 and ISP7. Growth was moderate on ISP-5 and ISP-6, while it was poor on ISP-4. The color of the aerial mycelia appeared gray or white to gray, while that of the substrate mycelia ranged from colorless or light to dark brown. The strain produced melanin pigment on ISP-6 and ISP-7. 
Phenotypic characteristics of strain SCY114. Phenotypic characteristics of strain SCY114 and related S. scabies strains are shown in table 2. The strain could degrade starch, tyrosine and gelatin but did not degrade casein or xanthine. All of the above characteristics of strain SCY114 were consistent with those of S. scabies ATCC49173. Strain SCY114 could utilize L-arabinose, dextran, meso-inositol, raffinose, sucrose and xylose as carbon sources, indicating its wide pattern of carbon assimilation. However, the strain grew well at $10^{\circ} \mathrm{C} \sim 40^{\circ} \mathrm{C}$ on $\mathrm{G}-1$ agar media and produced melanin, a temperature-sensitive pigment, at $35^{\circ} \mathrm{C} \sim 40^{\circ} \mathrm{C}$. In addition, strain SCY114 exhibited salt tolerance up to $5 \%$ and grew well in $\mathrm{pH}$ 5 8.

Table 2- Physiological biochemical characteristics of strain CY114, S. scabies ATCC 49173 and S. scabiei PK-A41

\begin{tabular}{|c|c|c|c|}
\hline Characteristic & $\begin{array}{l}\text { Strain SCY114 } \\
\text { CGMCC } 5213\end{array}$ & $\begin{array}{l}\text { S. scabies } \\
\text { ATCC } 49173\end{array}$ & $\begin{array}{l}\text { S. scabiei } \\
\text { PK-A41 a }\end{array}$ \\
\hline Formation of aerial mycelium & + & + & + \\
\hline $\begin{array}{l}\text { Spore chain morphology } \\
\text { Rectiflexibles and Spirals }\end{array}$ & + & + & + \\
\hline Spore surface & Smooth & Smooth & Smooth \\
\hline Melanin production on ISP-6 medium & + & + & + \\
\hline $\begin{array}{l}\text { Melanin production on ISP-7 medium } \\
\text { Degradation of }\end{array}$ & + & + & - \\
\hline Gelatin & $b+$ & + & - \\
\hline Starch & + & + & + \\
\hline Tyrosine & + & + & + \\
\hline Xanthine & - & - & + \\
\hline \multicolumn{4}{|l|}{$\begin{array}{l}\text { Growth on sole carbon source } \\
(1 \%, w / v)\end{array}$} \\
\hline L-Arabinose & + & + & + \\
\hline D-Fructose & - & + & + \\
\hline D-Glucose & + & + & + \\
\hline D-Mannitol & - & + & - \\
\hline meso-Inositol & + & + & + \\
\hline Raffinose & + & + & - \\
\hline L-rhamnose & + & + & - \\
\hline Sucrose & + & + & + \\
\hline Xylose & + & + & + \\
\hline \multicolumn{4}{|l|}{ Growth temperature range $\left({ }^{\circ} \mathrm{C}\right)$} \\
\hline 4 & - & - & - \\
\hline 10 & + & + & + \\
\hline 30 & + & + & + \\
\hline 40 & $\begin{array}{l}+ \text { (Melanin } \\
\text { production) }\end{array}$ & + & + \\
\hline 45 & - & - & - \\
\hline \multicolumn{4}{|l|}{ Growth of pH } \\
\hline 3 & - & - & - \\
\hline 5 & + & + & - \\
\hline 8 & + & + & + \\
\hline 11 & + & + & - \\
\hline 13 & - & - & - \\
\hline Max $\mathrm{NaCl}$ tolerance $(\%, \mathrm{w} / \mathrm{v})$ & 5 & 6 & 9 \\
\hline
\end{tabular}

a Date from Han, et al. 2004

b Symbols "+" and "-" represent positive and negative reaction, respectively.

Chemotaxonomic characteristics of strain SCY114. Compared to standard diaminopimelic acid (DAP), the DAP in the cell wall extract of strain SCY114 was identified as LL-DAP (data not shown), and the cell wall was characterized as Type I. The melting temperature and guanine plus cytosine content were $81.8^{\circ} \mathrm{C}$ and 61.6 $\mathrm{mol} \%$, respectively. A comparison of the fatty acid profiles of strain SCY114 and S. scabies ATCC49173 is given in Table 3, and there are differences in the proportions of some fatty acids. The cellular fatty acid of strain SCY114 mainly consisted of anteiso-C15:0
(20.32\%), iso-C16:0 (19.73\%), iso-C15:0 (12.14\%) and C16:0 $(11.26 \%)$, and that of S. scabies ATCC49173 mainly included isoC16:0 (16.28\%), anteiso-C15:0 (15.88\%), C16:0 (15.84\%) and anteiso-C17:0 (10.99\%). The DNA-DNA relatedness between strain SCY114 and S. scabies ATCC49173 was $65.2 \%$, which is below the $70 \%$ threshold value for the recognition of genomic species $[40,51]$.

Table 3- Cellular fatty acid profiles of the strain SCY114 and S. scabies ATCC49173

\begin{tabular}{|lll|}
\hline Fatty acid & Strain SCY114 $(\%)$ & S. scabies ATCC49173 (\%) \\
\hline iso-C14:0 & 4.48 & 1.46 \\
C14:0 & 1.14 & - \\
iso-C15:0 & 12.14 & 7.85 \\
anteiso-C15:0 & 20.32 & 15.88 \\
C16:0 & 11.26 & 15.84 \\
iso-C16:0 & 19.73 & 16.28 \\
iso-C16:1 H & 1.43 & - \\
iso-C16:1 w7c/16:1w6c & 6.44 & 8.41 \\
iso-C17:0 & 3.27 & 3.66 \\
anteiso-C17:0 & 7.64 & 10.99 \\
cyclo-C15:0 & 2.81 & 2.3 \\
iso-C17:1 w9c & 3.99 & 5.59 \\
anteiso-C17:1 w9c & 2.79 & 3.52 \\
C17:1 w8c & - & 1.04 \\
C18:0 10-methyl & - & 1.7 \\
\hline
\end{tabular}

*means not detected

\section{Analysis of the 16S rRNA gene sequence of strain SCY114:}

The 16S rRNA gene sequence of strain SCY114 (GenBank accession No. GU045542, $1519 \mathrm{nt}$ ) was aligned with the Streptomyces nucleotide sequences derived from GenBank. The Megalign program was used to determine the generic relationship between strain SCY114 and other S. scabiei strains. Strain SCY114 grouped most closely with S. scabies ATCC49173 and S. scabiei PK-A41 (Fig. 2), and the sequence similarities were $99.8 \%$ and $99.7 \%$, respectively.

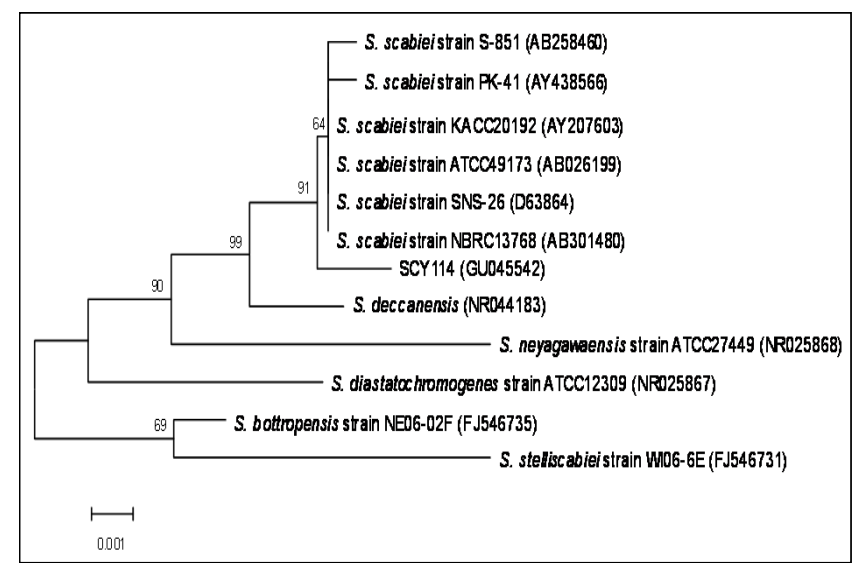

Fig. 2- Phylogenetic tree derived from $16 \mathrm{~S}$ rRNA gene sequence showing the relationship between strain SCY114 and its neighborhood strains. Bootstrap values are expressed as percentages of 1000 replications. Bar. 0.001 substitutions per nucleotide position.

Pathogenicity of strain SCY114. Strain SCY114 did not induce necrosis and collapse symptoms on the inoculated potato tubers. The strains S. scabies ATCC49173 caused pitted scab symptoms and pitted lesions without a ridge of raised tissue surrounding the 
pit. This result suggested that strain SCY114 differed from S. scabiei in that it showed no pathogenicity towards the potato plants.

\section{Antifungal Activity Assay in Vitro.}

The antifungal activity of strain SCY114 was evaluated using plant pathogenic fungi growth inhibition assays. Strain SCY114 exhibited strong inhibitory action against the growth of the test plant pathogenic strains (Fig. 3). Moreover, an ethyl acetate extract from the culture broth of strain SCY114 contained potent metabolites against the plant pathogenic fungi, as well as activity against test strains of phytopathogenic fungi (data not shown).

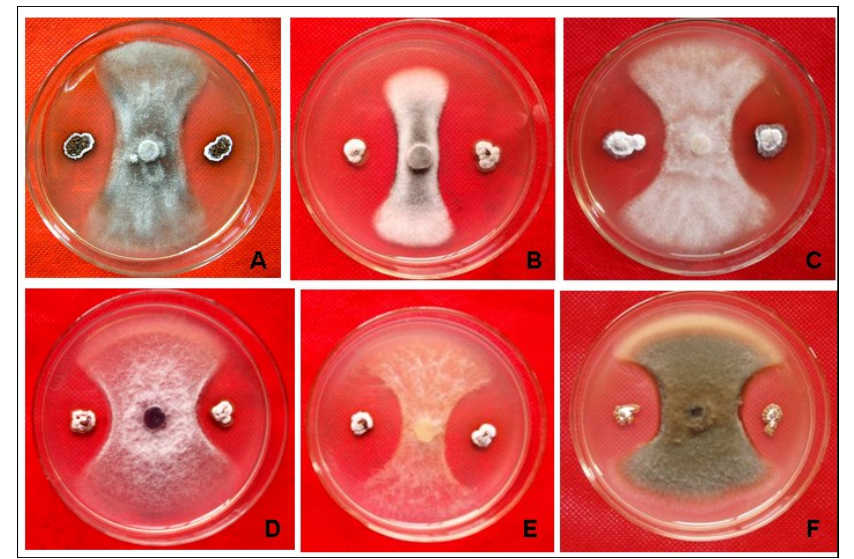

Fig. 3- Inhibition effect of strain SCY114 on plant pathogenic fungi.

A- Gaeumannomyces graminis var. tritici, B- Colletotrichum orbiculare, C- Phytophthora capsici, D- Pythium graminicola, E- Rhizoctonia cerealis, F- Ustilaginoidea virens

\section{Greenhouse Experiments for Biocontrol Activity Against Wheat take-all}

The in vivo efficacy of the filtered fermentation broth of strain SCY114 for the control of wheat take-all was evaluated under greenhouse conditions, and wheat take-all disease incidence and disease indexes were assessed for each treatment. The disease incidence and disease index of the wheat plant in the controls were significantly higher than the values measured with the filtered broth and silthiofam treatments (Table 4).

Table 4- Control effect of the strain SCY114 fermentation broth filter and Silthiofam on Wheat take-all in greenhouse experiments

\begin{tabular}{|c|c|c|c|}
\hline Treatment & Disease incidence $(\%)$ & Disease index & Disease reduced (\%) \\
\hline CK & $72.1 \mathrm{a} \pm 1.7$ & $56.3^{a} \pm 1.6$ & - \\
\hline Silthiofam & $27.2^{b} \pm 2.4$ & $22.9^{b} \pm 2.3$ & 59.3 \\
\hline Broth filter & $16.2^{\circ} \pm 1.4$ & $12.3^{c} \pm 1.5$ & 78.2 \\
\hline
\end{tabular}

Note: Different letters within columns indicate a significant difference, white same letters denote non-difference $(P \leq 0.05)$

Compared to the control plants, based on disease index, the filtered broth and silthiofam treatment reduced wheat take-all disease by $78.2 \%$ and $59.3 \%$, respectively. Application of the filtered broth from strain SCY114 proved to be significantly more effective at controlling wheat take-all than treatment with the fungicide silthiofam. These results revealed that the active substance produced by the strain SCY114 played an important role in wheat take-all disease suppression.

\section{Structural Elucidation of the Antifungal Compound}

The antifungal compound was obtained as a buff solid and was soluble in dimethylsulfoxide and dimethyl formamide, slightly soluble in $\mathrm{MeOH}$ and $\mathrm{CHCl}_{3}$, and insoluble in cyclohexane and water. The relative molecular mass of the active compound was estimated to be $466 \mathrm{Mr}$ according to ESI-MS: $\mathrm{m} / \mathrm{z} 467.2[\mathrm{M}+\mathrm{H}]^{+}$and 933.4 $[2 \mathrm{M}+\mathrm{H}]^{+}$. The ${ }^{1} \mathrm{H}$ NMR $\left(500 \mathrm{MHz}, \mathrm{DMSO}-\mathrm{d}_{6}\right)$ spectrum displayed signals for three methyls $\left[\delta_{\mathrm{H}} 3.34\left(3 \mathrm{H}, \mathrm{s}, \mathrm{H}-8^{\prime}\right), 2.31\left(3 \mathrm{H}, \mathrm{s}, \mathrm{H}-7^{\prime}\right)\right.$, and $\left.1.44\left(3 \mathrm{H}, \mathrm{s}, \mathrm{H}-7^{\prime}\right)\right]$ upfield and some olefinic hydrogen atoms downfield. The HMQC spectrum indicated that there were two hydrogen atoms $\left[\delta_{\mathrm{H}} 8.56(1 \mathrm{H}, \mathrm{s}, \mathrm{H}-6)\right.$ and $\left.4.14\left(1 \mathrm{H}, \mathrm{s}, \mathrm{H}-10^{\prime}\right)\right]$ that linked to nitrogen atoms. The ${ }^{13} \mathrm{C}$ NMR $\left(125 \mathrm{MHz}, \mathrm{DMSO}-d_{6}\right)$ spectra displayed 28 carbon signals, which were assigned to 1 oxymethyl $\left[\delta_{\mathrm{C}} 57.1\left(\mathrm{CH}_{3}, \mathrm{C}-8^{\prime}\right)\right]$, 2 methyls $\left[\delta_{\mathrm{C}} 29.7\left(\mathrm{CH}_{3}, \mathrm{C}-7^{\prime}\right), 33.2\left(\mathrm{CH}_{3}\right.\right.$, C-9')], 2 methylenes [ $\left.\delta_{C} 45.3\left(\mathrm{CH}_{2}, \mathrm{C}-7\right), 29.3\left(\mathrm{CH}_{2}, \mathrm{C}-5^{\prime}\right)\right], 1$ carbonyl $\left[\delta_{c} 172.1(\mathrm{C}, \mathrm{C}-5)\right]$ and other olefinic carbons. The molecular formula of the active compound was determined to be $\mathrm{C}_{28} \mathrm{H}_{26} \mathrm{~N}_{4} \mathrm{O}_{3}$ according to the above analysis. On the basis of the NMR, ${ }^{1} \mathrm{H}-{ }^{1} \mathrm{H}$ COSY and HMBC data (Table 5), the structure of the active compound was confirmed to be identical to staurosporine, which was consistent with previous reports $[32,35,41]$.

Table 5- ${ }^{1} \mathrm{H}$ NMR and ${ }^{13} \mathrm{C}$ NMR data of the active compound

\begin{tabular}{|c|c|c|c|c|}
\hline Position & $\delta_{c}$ & $\delta_{H}(\mathrm{~J}$ in $\mathrm{Hz})$ & ${ }^{1} \mathrm{H}-{ }^{1} \mathrm{H}$ COSY & HMBC \\
\hline 1 & $108.2(\mathrm{CH})$ & $7.59(1 \mathrm{H}, \mathrm{d}, 8)$, & $\mathrm{H}-2$ & C-3, C-4a \\
\hline 2 & $124.7(\mathrm{CH})$ & $7.46(1 \mathrm{H}, \mathrm{t}, 7.5)$, & $\mathrm{H}-1, \mathrm{H}-3$ & C-4, C-13a \\
\hline 3 & $118.9(\mathrm{CH})$ & $7.28(1 \mathrm{H}, \mathrm{t}, 7.5)$, & $\mathrm{H}-2, \mathrm{H}-4$ & $C-1$ \\
\hline 4 & $125.5(\mathrm{CH})$ & $9.28(1 \mathrm{H}, \mathrm{d}, 7.5)$, & $\mathrm{H}-3$ & $C-4 b, C-13 a$ \\
\hline $4 a$ & $122.4(\mathrm{C})$ & & & \\
\hline $4 \mathrm{~b}$ & $113.3(\mathrm{C})$ & & & \\
\hline $4 \mathrm{c}$ & $118.7(\mathrm{C})$ & & & \\
\hline 5 & 172.1 (C) & & & \\
\hline 6 & & $8.56(1 \mathrm{H}, \mathrm{s})$ & $\mathrm{H}-7$ & C-4c, C-5, C-7, C-7a \\
\hline 7 & $45.3\left(\mathrm{CH}_{2}\right)$ & $4.96(2 \mathrm{H}, \mathrm{s})$ & $\mathrm{H}-6$ & C-7b, C-4c, C-7a, C-5 \\
\hline $7 a$ & $131.9(\mathrm{C})$ & & & \\
\hline $7 \mathrm{~b}$ & $114.0(\mathrm{C})$ & & & \\
\hline $7 \mathrm{c}$ & 123.8 (C) & & & \\
\hline 8 & $120.7(\mathrm{CH})$ & $7.96(1 \mathrm{H}, \mathrm{d}, 7)$ & $\mathrm{H}-9$ & $C-7 b, C-11 a$ \\
\hline 9 & 119.6 (CH) & $7.28(1 \mathrm{H}, \mathrm{d}, 7)$ & $\mathrm{H}-8, \mathrm{H}-10$ & \\
\hline 10 & $124.2(\mathrm{CH})$ & $7.42(1 \mathrm{H}, \mathrm{d}, 8)$ & $\mathrm{H}-9, \mathrm{H}-11$ & C-8, C-11a \\
\hline 11 & $115.1(\mathrm{CH})$ & $7.97(1 \mathrm{H}, \mathrm{d}, 8.5)$ & $H-10$ & C-7c \\
\hline $11 a$ & $139.3(\mathrm{C})$ & & & \\
\hline $12 \mathrm{a}$ & 129.9 (C) & & & \\
\hline $13 a$ & $136.2(C)$ & & & \\
\hline $2^{\prime}$ & $91.0(C)$ & & & \\
\hline $3^{\prime}$ & $82.7(\mathrm{CH})$ & $4.07(1 \mathrm{H}, \mathrm{s})$ & $H-4^{\prime}$ & C-2', C-7', C-8' \\
\hline $4^{\prime}$ & $49.9(\mathrm{CH})$ & $3.26(1 \mathrm{H}, \mathrm{s})$ & $\begin{array}{l}\mathrm{H}-3, \mathrm{H} \\
\mathrm{H}-10^{\prime}\end{array}$ & $\mathrm{C}-2, \mathrm{C}-3, \mathrm{C}-5$ \\
\hline $5^{\prime}$ & $29.3\left(\mathrm{CH}_{2}\right)$ & $2.51(2 \mathrm{H}, \mathrm{s})$ & H-4, H-6' & $C-3^{\prime}, C-4^{\prime}, C-6^{\prime}$ \\
\hline $6^{\prime}$ & $79.8(\mathrm{CH})$ & $6.71(1 \mathrm{H}, \mathrm{s})$ & $\mathrm{H}-5^{\prime}$, & $C-2^{\prime}, C-12 b, C-13 a$ \\
\hline $7^{\prime}$ & $29.7\left(\mathrm{CH}_{3}\right)$ & $2.31(3 \mathrm{H}, \mathrm{s})$ & & C-2', C-3', C-6' \\
\hline $8^{\prime}$ & $57.1\left(\mathrm{CH}_{3}\right)$ & $3.34(3 \mathrm{H}, \mathrm{s})$ & & C- $3^{\prime}$ \\
\hline $9^{\prime}$ & $33.2\left(\mathrm{CH}_{3}\right)$ & $1.44(3 \mathrm{H}, \mathrm{s})$ & & C-4' \\
\hline $10^{\prime}$ & & $4.14(1 \mathrm{H}, \mathrm{s})$ & & \\
\hline
\end{tabular}

\section{Discussion}

S. scabiei was first isolated in 1890 in Connecticut and named Oospora scabies [45], then Actinomyces scabies by Gussow [11] and, finally, Streptomyces scabiei by Waksman and Henrici [20]. Elesaway and Szabo [6] revaluated the species and offered an acceptable neotype strain (strain ATCC33282) and expanded the original description to include smooth spores and use of all ISP sugars. However, the species did not appear on the Approved Lists of Bacterial Names, which was published shortly thereafter [39]. 
The revival name, S. scabies, was redefined by Lambert and Loria [20] and characterized as exhibiting smooth gray spores borne in spiral chains, melanin production, and usage of all of the ISP sugars. The streptomycete strain SCY114 was isolated from a soil sample in Henan Province, China, in 2010, and the morphological characteristics were consistent with those of $S$. scabies ATCC49173, S. scabiei PK-A41 and S. scabiei subsp. chosunensis M0137, i.e., the aerial mycelia are gray on ISP media, the spores are smooth and borne on mature rectiflexible or spiral chains, and melanin is produced on tyrosine agar and peptone iron agar. The phyenotypic characteristics of strain SCY114 are similar to those of S. scabies ATCC49173, except for the usage of D-Fructose and DMannitol. However, the $\mathrm{NaCl}$ tolerance of strain SCY114 was different from those of S. scabies ATCC49173. In addition, strain SCY114 produced melanin, a temperature-sensitive pigment, at $35^{\circ} \mathrm{C} \sim 40^{\circ} \mathrm{C}$.

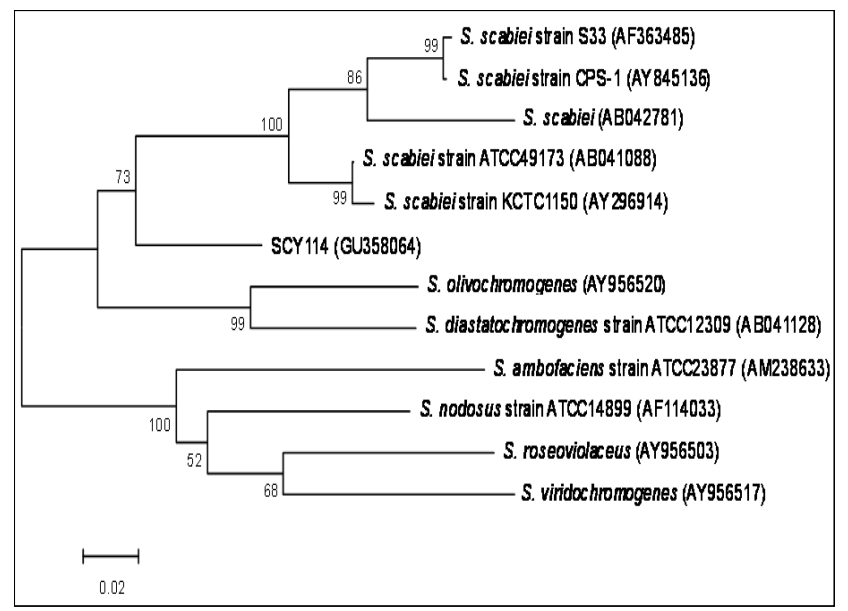

Fig. 4- Phylogenetic tree derived from 16S 23S rRNA ISR gene sequence showing the relationship between strain SCY114 and its neighborhood strains. Bootstrap values are expressed as percentages of 1000 replications. Bar. 0.02 substitutions per nucleotide position.

In the phylogenetic tree based on the 16S rRNA gene sequences, the neighboring strains of strain SCY114 clustered within the group of S. scabiei and shared the highest similarities with S. scabies ATCC49173 (99.8\%) and S. scabiei PK-A41 (99.7\%). However, this value was lower than the levels between strains belonging to the species S. scabiei which were more than 99.9\% [42]. Although the 16S rRNA gene has emerged as a "gold standard" for determining the phylogenetic relationships of bacteria [30,40,53], some investigators have questioned whether sufficient variability exists in 16S rRNA to allow the discrimination among species of a genus or strains of a species [10]. The 16S 23S rRNA internal transcribed spacer (ITS), or ISR, has been suggested as a potential target within the bacterial genome to find suitable sites for probes and from which to derive additional phylogenetic information. While the 16S rDNA sequence is a good tool for inferring inter- and intrageneric relationships, 16S-23S rRNA spacer sequence comparisons provide information concerning the intraspecific links and allow researchers to detect recently diverged species [21]. Thus, ITS or ISR sequences have been proposed to be a useful supplement when 16S rRNA gene sequences exhibit insufficient diversity to differentiate closely related species $[11,31]$. In this study, the 398 - nt 16S 23S rRNA ISR sequence of strain SCY114 was PCR amplified and sequenced ( GenBank accession No. GU358064). The phylogenetic analysis based on the 16S 23S rRNA ISR sequences indicated that strain SCY114 formed a distinct phyletic lineage with S. scabiei strains, and the sequence similarity was $87.8 \%$ with $S$. scabies ATCC49173 (Fig. 4).

The DNA-DNA relatedness between strain SCY114 and S. scabies ATCC49173 was $65.2 \%$, which is below the $70 \%$ threshold value. Value of $\Delta T m$ between strain SCY114 and S. scabies ATCC49173 1 was $8.2^{\circ} \mathrm{C}$, which are greater than the $5^{\circ} \mathrm{C}$ cut-off point for the recognition of genomic species. Moreover, the pathogenicity of strain SCY114 significantly differed from that of $S$. scabies ATCC49173 towards potato plants.

Based on the phenotypic and genotypic evidence, strain SCY114 was identified as a subspecies of the Streptomyces scabiei, for which the name Streptomyces scabiei subsp. xuchangensis. (CGMCC 5213) is proposed.

Strain SCY114 grown on PDA medium was tested for its antifungal activities against the mycelial growth of various plant pathogenic fungi. Strain SCY114 strongly inhibited the in vitro mycelial growth of Gaeumannomyces graminis var. tritici and various other plant pathogenic fungi. Additionally, the filtered culture broth of strain SCY114 was significantly more effective at controlling wheat takeall compared to silthiofam. It may be assumed that strain SCY114 exerts its effective suppression of wheat take-all via its secondary metabolites. Therefore, the filtered broth of strain SCY114 was investigated for the presence of an antibiotic substance, which was subsequently characterized. The molecular formula of the antibiotic was determined to be $\mathrm{C}_{28} \mathrm{H}_{26} \mathrm{~N}_{4} \mathrm{O}_{3}$, and on the basis of the NMR data, the antibiotic was identified as staurosporine.

Staurosporine, an indolo[2,3-a]carbazole alkaloid antibiotic, was first isolated in 1977 from S. staurosporeus [33] and, subsequently, from other Streptomyces strains, e.g., S. actuosus [29], S. roseoflavus [35], Streptomyces sp. strain M-193 [32] and Streptomyces sp. strain 11 [36]. Staurosporine possesses inhibitory activity against fungi and yeasts but has no significant effects on bacteria [28,34]. Furthermore, staurosporine exhibits strong inhibitory activities against protein kinase $\mathrm{C}$, as well as inhibition of platelet aggregation, the blocking of growth phases in cancer cells and the reversal of multidrug resistance [46]. To our knowledge, this is the first study to isolate staurosporine from Streptomyces scabies subsp. xuchangensis, the novel Streptomycete strain SCY114, and demonstrate its potential to control wheat take-all disease.

\section{Acknowledgements}

This work was supported by the Henan Major Commonwealth Scheme (Project No. 0811090911300). We thank Dr. Zhou Yuanming for the structural assays of the antibiotic and the China General Microbiological Culture Collection Center (CGMCC) for the guanine-plus-cytosine content, DNA-DNA hybridization, and cellular fatty acid determination.

\section{References}

[1] Agrios G.N. (2005) Plant Pathology., 5th ed., 343.

[2] Becker B.M., Lechevalier P., Gorden R.E., Lechevalier H.A. (1964) Appl. Microbiol., 12, 421-423. 
[3] Bramwell P.A., Wiener P., Akkermans A.D.L., Wellington E.M.H. (1998) Lett. Appl. Microbiol., 27, 255-260.

[4] Duval I., Brochu V., Simard S., Beaulieu C., Beaudoin N. (2005) Planta., 222, 820-831.

[5] Edwards U., Rogall T., Blocker H., Emde M., Bottger E.C. (1989) Nucleic Acids Res., 17, 7843-7853.

[6] Elesaway A.A., Szabo J.M. (1979) Acta. Microbiol. Acad. Sci. Hung., 26, 311-320.

[7] Errakhi R., Dauphin A., Meimoun P., Lehner A., Reboutier D., Vatsa P., Briand J., Madiona K., Rona J.P., Barakate M., Wendehenne D., Beaulieu C. and Bouteau F. (2008) J. Exp. Bot., 59, 4259-4270.

[8] Felsenstein J. (1985) Evol., 39, 783-791.

[9] Fox G.E., Wisotzkey J.D., Jurtshuk P. (1992) Microbiol., 142, 316.

[10]Gtirtler, V., Stanisich, V.A. (1996) Microbiol., 142, 3-16.

[11] Gussow H.T. (1914) Science, 39, 431432.

[12]Han W.C., Lee J.Y., Park D.H., Lim C.K. and Hwang B.K. (2004) Plant Pathol. J., 20, 115-126.

[13] He L., Li W., Huang Y., Wang L., Liu Z., Lanoot B., Vancanneyt M. and Swings J. (2005) Int. J. Syst. Evol. Microbiol., 55, 19391944.

[14]Huang L.L., Korschenhaus J.W., Heppner C., Buchenauer H. (2001) Nachrichtenblatt des Deutschen Pflanzenschutzdienstes., 53, 165-171.

[15]Jansen M.A., Webster J.A., Strans N. (1993) Appl. Environ. Microbiol., 59, 945-952.

[16]Kavitha A., Prabhakar P., Vijayalakshmi M. and Venkateswarlu Y. (2010) Res. Microbiol., 161, 335-345.

[17]Kimura M. (1980) J. Mol. Evol., 16, 111-120.

[18]Korn-Wendisch F. and Kutzner H.J. (1992) The family Streptomycetaceae, 921-983.

[19]Kroppenstedt R.M. (1985) Fatty Acid and Menaquinone Analysis of Actinomycetes and Related Organisms, 173-199.

[20]Lambert D.H., Loria R. (1989) Int. J. Syst. Bacteriol., 39, 387392.

[21]Leblond-Bourget N., Philippe H., Mangin I. and Decaris B. (1996) Int. J. Syst. Bacteriol., 46, 102-111.

[22]Lechevalier H.A., Lechevalier M.P. (1970) A Critical Evaluation of the Genera of Aerobic Actinomycetes, 393-405.

[23]Lerat S., Babana A.H., El Oirdi M., El Hadrami A., Daayf F., Beaudoinm N., Bouarab K., and Beaulieu C. (2009) Plant Cell Rep., 28, 1895-1903.

[24]Loria R., Bukhalid R.A., Creath R.A., Leiner R.H., Olivier M. and Steffens J.C. (1995) Phytopathol., 85, 537-541.

[25]Loria R., Bukhalid R.A., Fry B.A. and King R.R. (1997) Plant Dis., 81, 836-846.
[26]Marmur J. and Doty P. (1962) J. Mol. Biol., 5, 109-118.

[27]McManus P.S., Stockwell V.O., Sundin G.W. and Jones A.L. (2002) Annu. Rev. Phytopathol., 40, 1143-1165.

[28]Meksuriyen D., Cordell G.A. (1998) J. Nat. Prod., 51, 893-899.

[29]Morioka H., Ishihara M., Shibai H., Suzuki T. (1985) Agric. Biol. Chem., 49, 1959-1967.

[30]Mullie C.J. (2006) Use of 16S rRNA Gene Sequence for the Description of New Species, 270-272.

[31]Nguimbi E., Li Y.Z., Gao B.L., Li Z.F., Wang B., Wu Z.H., Yan B.X., Qu Y.B. and Gao P.J. (2003) Syst. Appl. Microbiol., 26, 262-268.

[32]Oka S., Kodama M., Takeda H., Tomizuka N., Suzuki H. (1986) Agric. Biol. Chem., 50, 2723-2727.

[33]Omura S., Iwai Y., Hirano A., Nakagawa A., Awaya J., Tsuchya H., Takahashi Y., Masuma R. (1977) J. Antibiot., 30, 275-282.

[34]Omura S., Sasaki Y., Iwai Y., Takeshima H. (1995) J. Antibiot., 48, 535-548.

[35]Park H.J., Lee J.Y., Hwang I.S., Yun B.S., Kim B.S., Hwang B.K. (2006) J. Agric. Food Chem., 54, 3041-3046.

[36]Pimentel-Elardo S.M., Kozytska S., Bugni T.S., Ireland C.M., Moll H. and Hentschel U. (2010) Mar. Drugs., 8, 373-380.

[37]Saitou N. and Nei M. (1987) Mol. Biol. Evol., 4, 406-425.

[38]Shirling E.B. and Gottlieb D. (1966) Int. J. Syst. Bacteriol., 61, 313-340.

[39]Skerman V.B.D., McGowan V. and Sneath P.H.A. (1980) Int. J. Syst. Bacteriol., 30, 225-420.

[40]Stackebrandt E. and Goebel B.M. (1994) Int. J. Syst. Bacteriol., 44, 846-849.

[41]Takahashi I., Saitoh Y., Yoshida M., Sano H., Nakano H., Morimoto M., Tamaoki T. (1989) J. Antibiot., 42, 571-576.

[42] Takeuchi, T., Sawada, H., Tanaka, F., and Matsuda, I. (1996) Int. J. Syst. Bacteriol., 46, 476-479.

[43]Tamura K., Dudley J., Nei M., Kumar S. (2007) Mol. Biol. Evol., 24, 1596-1599.

[44]Tegg R.S, Melian L., Wilson C.R., Shabala S. (2005) Plant Cell Physiol., 46, 638-648.

[45] Thaxter R. (1891) Agric. Expt. Sta. Rept., 1890, 81-95.

[46]Utz I., Spitaler M., Rybczynska M., Ludescher C., Hilbe W., Regenass U., Grunicke H., Hofmann J. (1998) Int. J. Cancer., 77, 64-69.

[47]Valois D., Fayad K., Barasubiye T., Garon M., Dery C., Brzezinski R., Beaulieu C. (1996) Appl. Environ. Microbiol., 62, 1630-1635.

[48]Waksman S.A. (1961) Classification, Identification and Descriptions of Genera and Species, 1-363.

[49]Wan M.G., Li G.Q., Zhang J.B., Jiang D.H., Huang H.G. (2008) 
Biol. Control., 46, 552-559.

[50]Watve M.G., Tickoo R., Jog M.M., Bhole B.D. (2001) Arch. Microbiol., 176, 386-90.

[51]Wayne L.G., Brenner D.J., Colwell R.R., Grimont P.A.D., Kander O., Krichevsky M.I., Moore L.H., Moore W.E.C., Murray R.G.E., Stackebrandt E., Starr M.P., Truper H.G. (1987) Int. J. Syst. Bacteriol., 37, 463-464.

[52]Williams S.T., Sharpe M.E., Holt J.G., Murray R.G.E., Brener D.J., Krieg N.R., Mouldar J.W., Pfennig N., Sneath P.H.A., Staley J.T. (1989) Bergeys Manual of Systematic Bacteriology, IV, Williams and Wilkins Co., Baltimore.

[53]Woese C.R. (1987) Microbiol. Rev., 51, 221-271.

[54]Yoo J.C., Han J.M., Nam S.K., Baik K.S., Jo J.S., Seong C.N. (2002) J. Microbiol., 40, 178-181.

[55]Yoo J.C., Han J.M., Nam S.K., Ko O.H., Choi C.H., Kee K.H., Sohng J.k., Jo J.S., Seong C.N. (2002) J. Microbiol., 40, 331334. 